\title{
The Pharmaceutical Year That Was, 2019
}

\author{
Anthony W. Fox ${ }^{1}$
}

Published online: 15 November 2019

(c) Springer Nature Switzerland AG 2019
There seems to have been a greater than usual invasion into pharmaceutical medicine by the legal industry this year. Some of this is commercial and financial. However, some, quite clearly, involves serious clinical hazards, where the ultimate remedy is going to be clinical practice, not at law.

At the end of 2018 the UK Supreme Court handed a victory to Mylan in its long-running dispute with Pfizer over whether its generic pregabalin was infringing the innovator's patent ${ }^{1}[1]$. While the judgment favoured the generic competitor, more importantly there was a clarification over what has been a 'grey' area in patent law. Pregabalin had initially been approved for epilepsy and anxiety disorders. Its composition of matter patents (i.e. the molecule design) have long since expired. However, in 1996, the innovator took out a patent for a new use of pregabalin: neuropathic pain. This is a so-called 'method of use' or 'Swiss-style' patent, and has claims restricted to the new use [2]. The generic company challenged the innovator's 1996 patent on grounds of sufficiency of description (there was actually neither rationale nor data for the treatment of neuropathic pain), and in 2015, Mylan went ahead and launched its generic pregabalin. Two lower courts dismissed Pfizer's claims of patent infringement, by using two different 'legal tests' which hinged on whether the generic product was being marketed only for the old epilepsy-type indications (i.e. not infringing the new method of use patent) and whether it was also selling into the neuropathic pain market. The Supreme Court has now dismissed Pfizer's appeal on a novel basis: the 1996 patent has been declared invalid using a third legal test. This new legal test is based on whether the outward appearance of the product suggests that it is intended for use in the off-patent indication, and basically relies on what the package insert says. Since generic pregabalin was labelled only for epilepsy and anxiety, the Supreme Court reckons that it was beyond

\section{Anthony W. Fox}

afox05@bbk.ac.uk

1 Editor Emeritus, Pharmaceutical Medicine, Birkbeck College, University of London, Malet Street,

London WC1E 7HX, UK
Mylan's control what pharmacists and prescribers (P\&P) might then do with the product. Pfizer's appeal was therefore dismissed. Furthermore, the court decided that the clinicians are not patent infringers because of section $4 \mathrm{~A}$ of The Patents Act 1977 of the $\mathrm{UK}^{2}$ [2]. The decision brings clarity, and this support for generic drugs, given their favourable pricing, will doubtlessly be welcomed by a largely socialised healthcare system paying for drugs. However, it would also appear to have reduced the financial incentives for phase IV research and wider types of drug-repurposing (this is especially so for orphan indications). Innovators also seem to have an avenue open to them to strengthen the enforceability of method of use patents, by making small changes in dose size with purpose-designed labelling for their new indication. That is, until some clever patent lawyer finds a quicker way around their Lordships' decision.

At the beginning of the year, the Institute of Cancer Research produced a report entitled 'From patent to patient', which looked at the pace of drug approval in oncology [3]. The good news is that the number of market authorisations of drugs for cancer has been accelerating for almost a decade now and continues to do so. This increase in oncology approvals has, however, been uneven: in particular, cancer in children, the oesophagus, the brain and the uterus have been very underserved, or, at least, few new drugs to treat them have been successful. Moreover, development projects are taking longer: decade on decade, there has been a mean increase in overall patent-to-National Institute for Health and Clinical Excellence (NIHCE) approval time from 12.7 to 14.1 years, and the shortest interval between starting phase I to the earliest European Medicines Agency (EMA) Market Application Approval (MAA) has grown from 7.8 to 9.1 years. Meanwhile, things have also changed at the NIHCE (formerly 'NICE', the 'UK drugs watchdog' according to the

\footnotetext{
1 The judgment was handed down November 14, 2018, and applies to at least three different cases, involving the same issues, in the lower courts.

2 This type of patent is a complicated legal construction because of the need to evade section 4A of The Patent Act 1977 (UK), which actually forbids methods of treatment and diagnosis from being awarded protection.
} 
popular press). The NIHCE opine on whether the National Health Service in England and Wales ought to pay for new drugs. Commendably, NIHCE is now starting its reviews of oncology drugs at a mean of 6.5 months after MAA approval (it had been 21.0 months during the previous decade), and the median latency is about zero months because NIHCE is now actually starting many reviews before the MAA is received. However, the mean length of the NIHCE reviews once begun has essentially not improved in 20 years (16.7 vs 16.0 months). What the report does not tell us is why the phase I-to-MAA interval has increased: Is it because reviews by the EMA are elongating or because the clinical development teams are slowing down? Is the latter inevitable as the demands of the former and the drug-regulators are ever-increasing?

Attention to the opioid over-use epidemic in the United States has grown massively this year, and in particular, it has developed a new focus over whether habituated patients should use treatments with a pharmacological component: this is so-called 'medication-assisted treatment' (MAT) [4].

Three drugs central to MAT are methadone, buprenorphine and naltrexone. None of these is a panacea, each is indicated for different types of MAT, and all have their own adverse effects (e.g. naltrexone, a pure opioid antagonist, cannot be used during detoxification). These MAT have encountered much denigration by politicians. For example, Secretary Tom Price, head of Health and Human Services (HHS) (i.e. its cabinet minister), has opined: "If we're just substituting one opioid for another, we're not moving the dial much" [5]; but then again, one cannot expect an orthopaedic surgeon to comprehend much about drug-receptor theory ${ }^{3}$ [6]. In any event, Mr. Price became one of the many short-term government departures under the present US President, and his replacement, Mr. Alex Azar, is a bit better balanced, having long experience within the HHS and even a few years in the pharmaceutical industry. Hopefully, MAT is now being assessed more objectively, using a cost-riskbenefit approach, and, surely, decisions about MAT should be taken by the patients and the trained clinicians who treat them, and not by people with political prejudices.

Further opioid fallout this year included a large pharmaceutical company paying US $\$ 1.4$ billion to the US Department of Justice for something that it did not seem to do. In the USA, Indivior ${ }^{\circledR}$ markets buprenorphine in the form of a film which can be absorbed in the mouth. Buprenorphine is a slow-onset, partial mu-opioid agonist [6] indicated for maintaining withdrawal from addictive opioids (due to its partial antagonist properties). Buprenorphine abuse has been reported, but the epidemic in the United States centres around (1) the prescribed analgesics oxycodone and

\footnotetext{
3 For other criticism of Mr. Price's statement, see also [17].
}

fentanyl (see below) and (2) unprescribed 'street drugs' such as morphine, heroin, (again) fentanyl, and non-opioids. After being indicted in the USA by a grand jury (a process abolished in the UK in 1933), Indivior ${ }^{\circledR}$ was still entitled to be presumed innocent until proven otherwise. The buprenorphine film, meanwhile, was Food and Drug Administration (FDA)-approved. Meanwhile Reckitt Benckiser ${ }^{\circledR}$, a parent of Indivior $^{\circledR}$, itself not indicted, nonetheless decided to pay the huge sum to resolve anything that might have arisen from an investigation [7]. The US Department of Justice, of course, conflated all this with the opioid abuse epidemic, with selfserving enthusiasm-“"The opioid epidemic continues to be a serious crisis for our nation, and I'm proud of the work the Department of Justice and our partners are doing to address this epidemic," said Principal Deputy Associate Attorney General Claire Murray' [8]—-thus demonstrating apparent obliviousness that the product in question is an approved treatment and part of the fight against that epidemic. The Reckitt Benckiser ${ }^{\circledR}$ press release categorically denies all allegations of illegality and describes the payment as helping to avoid the uncertainties of litigation [9]. Finally, the latest round of litigation has ironically included the stipulation that the defendants should provide large amounts of buprenorphine film to the complainants (sic) (see the Ohio example [10]).

The EMA sustained further court sanctions this year. In January, the EMA found itself being a defendant in the Chancery Division of the UK High Court; its landlord wanted to enforce the terms of the EMA's 25-year lease (taken out in 2011) on premises in an area of London known as the Isle of Dogs. The biggest reason was about $£ 500$ million of unpaid rent [11]. Apparently, the EMA wanted to terminate its lease on the grounds that it is a 'frustrated contract' due to Brexit. This term 'frustrated' has a technical, legal meaning. A contract may be frustrated by subsequent events, similar to those fulfilling the force majeure terms that are written into most business contracts, and usually through no fault of the parties themselves. The concept was devised in the 19th century and held to terminate a contract when a music hall burned down in between the dates of booking and the actual musical performance [12]. Since then, the UK courts have made contract frustration somewhat arcane, and have interpreted it narrowly and variably. For example, the failure of King Edward VII to appear for his coronation (because he was having his appendix abscess drained by Sir Frederick Treves of the London Hospital) led to a finding of frustration for contracts renting upstairs rooms in Regent Street to would-be spectators of the Royal procession [13], while those who had hired a boat to pursue the review of the Imperial fleet could not get their money back [14]. In any case, the EMA lost; they are most recently reported to be trying 
to sub-let the premises ${ }^{4}$ [15]. Meanwhile, in Canary Wharf $v$ $E M A$, a simple Google search elicits that the two opponents have hired barristers from the same set (Joanne Wicks QC and Jonathan Seitler QC, both from Wilberforce at Lincoln's Inn) [15]. While one may wonder what they talk about over the morning coffee in chambers, the rest of us may remain frustrated (by any definition of the word) by Brexit.

On a brighter regulatory note, good science prevailed at the EMA this summer when it recommended marketing authorisation for larotrectinib (Bayer AG) [16]. Importantly, the approved indication is for solid tumours that display neurotrophic tyrosine kinase receptor (NTRK) gene fusion. This indication is not restricted to any particular organ (breast, colon, etc.) or histology (squamous carcinoma, small cell carcinoma, adenocarcinoma, etc.). This is rational given the molecular pharmacology of the drug. This also validates the 'umbrella' clinical trial design where patient recruitment is on the basis of a biomarker relating specifically to drug action and not to a particular tumour type.

Happy New Year!

\section{Compliance with Ethical Standards}

Funding No funding was provided for the publication of this editorial.

Conflict of interest Dr. Fox declares no conflicts of interest for this article.

\section{References}

1. Warner-Lambert Co. LLC v Generics UK t/a Mylan Laboratories [2018] UKSC 56, on appeal from [2016] EWCA Civ 1006.
2. The Patents Act 1977, UK, Sect. 4A.

3. Institute of Cancer Research (ICR). From patent to patient: analysing access to innovative cancer drugs. London: ICR Occasional Report, pp. 6-7, 17, 24-25.

4. Goodnough A. Feud over the use of drugs to curb the abuse of drugs. The New York Times December 30, 2018; CLXVIII (no. 58,192): 1, 19.

5. https://www.businessinsider.com/hhs-secretary-tom-price-medic ation-assisted-treatment-suboxone-news-opioid-crisis-20175 ? $\mathrm{r}=\mathrm{US} \& \mathrm{IR}=\mathrm{T}$. Accessed 24 Oct 2019.

6. Fox AW. Modern opioids: uses defined by chronopharmacology, not receptor selectivity. J R Soc Med. 1995;88:502-4.

7. English S. Reckitt shells out $£ 1$ bn to end US opioid drugs investigation. Evening Standard (London), July 11, 2019, p. 39.

8. US Department of Justice. Washington DC: press release July 11, 2019. https://www.justice.gov/opa/pr/justice-department -obtains-14-billion-reckitt-benckiser-group-largest-recovery-case. Accessed 1 Aug 2019.

9. https://www.rb.com/media/news/2019/july/rb-reaches-settlement -to-fully-resolve-all-federal-investigations/. Accessed 1 Aug 2019.

10. https://www.cnbc.com/2019/10/21/four-drug-companies-reach -a-settlement-as-opioid-trial-was-set-to-begin.html. Accessed 24 Oct 2019.

11. Times Business Staff. Canary Wharf in court fight amid 'Brexit' bid to quit lease. London: The Times January 17, 2019, p. 44.

12. Taylor v Caldwell [1863] 3 B\&S 826 Queen's Bench Division.

13. Krell v Henry [1903] 2 KB 740.

14. Herne Bay Steamboat v Hutton [1903] 2 KB 683.

15. Canary Wharf v European Medicines Agency (EMA) [2019] EWHC $335(\mathrm{Ch})$

16. European Medicines Agency. First 'histology-independent' treatment for solid tumours with a specific gene mutation. Amsterdam: European Medicines Agency EMA/CHMP/391684/2019.

17. https://www.statnews.com/2017/05/11/vivek-murthy-tom-price/. Accessed 1 Aug 2019.

\footnotetext{
4 The judgment against the EMA was handed down February 21, 2019; the High Court found that the lease was not 'frustrated' and that, under international and European law, there was no legal reason justifying the EMA to relocate to Amsterdam (see paragraphs 148155 of the Judgment [15])!
} 